Jurnal Pengabdian kepada Masyarakat

(Indonesian Journal of Community Engagement)
Vol.5, No.3, December 2019, pp. 416 - 436

DOI:http://doi.org/ 10.22146/jpkm.50783

\title{
Adoption of Agroforestry-Porang Model for Land Utilization under Teak Stands
}

Hermudananto, Dwiko Budi Permadi*, Ratih Madya Septiana, Slamet Riyanto, Andita Aulia Pratama

Departemen Manajemen Hutan, Fakultas Kehutanan UGM, Jl. Agro No.1, Bulaksumur, Sleman, Daerah Istimewa Yogyakarta, 55284

*dbpermadi@ugm.ac.id

Submitted: Oktober 23, 2019; Accepted: November 28, 2019

\begin{tabular}{ll}
\hline Keywords: & Abstract Banyusoco village in Gunungkidul has more than 60\% of its land as state \\
Amorphophallus & forests managed by several forest farmer groups in Community Forestry scheme \\
onchophillus; & (Hutan Kemasyarakatan-HKm) majority planted Teak (Tectona grandis). Problem \\
Community & of "delayed" revenue through harvesting slow-growing Teak stands could be \\
Forestry; & resolved by planting a type of tubers or empon-empon under the stand, so that \\
Community & forest floor may earn additional income. Our community service focuses on \\
Service; & introduction of Porang tuber plants (Amorphophallus oncocphyllus) to a) increase \\
Demonstration & environmental knowledge and skills of farmers in agroforestry-Porang cultivation; \\
Plot; Konnyaku & b) increase knowledge and skills of farmers in harvesting and managing post- \\
& harvest of Porang; c) increase farmers' income from Porang. Our first of three year \\
& activities program included institutional workshops and introduction of Porang \\
& cultivation, procurement of Porang seeds, development of demonstration plot, and \\
& facilitation on planting Porang under stands. Temporary result was a 0.5 ha- \\
& demonstration plot with 4,000 seeds supporting by HKm "Sedyo Rukun" which \\
& positively impacts in a) fostering cohesiveness of members with mutual cooperation \\
& every Thursday (Kamisan) in preparing and maintaining land; b) increasing \\
& members' understanding in cultivation Porang; c) becoming a portfolio in national \\
& HKm competition. Following year's community empowerment program continues to \\
& be focused on maintaining, harvesting and marketing Porang.
\end{tabular}

\section{INTRODUCTION}

Banyusoco Village is the largest village in Playen Subdistrict, Gunungkidul. It covers 2,053 ha with a population of 4,488 in 2015 (Desa Banyusoco, 2014). The majority of people work as farmers and farm laborers (69.1\%) (Desa Banyusoco, 2014), while majority education level is still relatively low dominated by elementary and junior high school (55\%) (Desa Banyusoco, 2014). Their principle "sing penting urip, iso mangan, turu, wes cukup" meaning "Can live, eat, and sleep is enough" indicated they have limited education, information, or skills to improve their quality of life which majority 
still rely on forest land for their livelihood, especially Teak (Tectona grandis) stands combining with other agricultural crops and livestock.

Since 2003 several forest farmer groups in Banyusoco village have also been given authority to manage community forestry (Hutan Kemasyarakatan-HKm) by the Ministry of Environment and Forestry with a total area of 57.4 ha for a period of 35 years. One HKm named "Sedyo Rukun" led by Ms. Sudarmi with majority of women members has right to manage Petak 95 in the RPH of Gora. Its area is planted with Teak trees that should be harvested in 2019-2021. However, their forest management activities are still limited to cultivate forestry stands (Teak, Mahogany, Sengon, Acacia) where in the beginning of period were combined with food crops and livestock forage (initial agroforestry stage). Along with growth of stands, the growing space of food crops under stands is decreasing and in the end only leaves forestry stands. Intrinsically, forestry stands' commodities have a long production period (low-growing species), so there is a 'delay' in revenue from timber products. To meet the income during rotation period, one of them is by optimizing forest land through planting shaded resistant-crops, tubers, or empon-empon, so that the "forest floor" could earn additional income through Land Utilization of under Stands (PLDT) program. However, its program often faces technical and non-technical constraints that could not fully adopted by the community and thus unable to achieve the desired goals. To optimize land under stands, supports from universities as a center for development of applied technology in the implementation of cultivation and processing is needed (Wahyono et al., 2017).

Porang is one of the high economic value tubers that has potentially to increase community income (Rofiqoh, 2018; Wahyono et al., 2017). The raw material for Porang flour (Konyaku) can be used for a variety of processed products, such as noodles 
(Shirataki) in Japan. With investment around 3 million rupiah per hectare, it has potentially to generate gross profit of approximately 12 million rupiah per year (Wahyono et al., 2017), or even greater (Rofiqoh, 2018). Cultivation in intercropping (or agroforestry) Porang plants with other perennials has begun to be widely practiced in several areas (Puspitorini et al., 2018; Rofiqoh, 2018; Wahyono et al., 2017) through community empowerment of community forestry $(\mathrm{HKm})$ as one of schemes. Community empowerment is seen as an effort to improve the capacity and independence of the community so that community can obtain the benefits of forest resources optimally and fairly through developing capacity and providing access in the context of community welfare. Therefore, it potentially to develop an agroforestry system of Porang as a community service program by Faculty of Forestry in Banyusoco Village, Gunung Kidul.

Our objectives on this community services are to mainly utilize land under forest stands (Teak) with the introduction of Porang tuber plants in the community forestry $(\mathrm{HKm})$ in Banyusoco village Gunungkidul to a) increase environmental knowledge and skills of farmers in agroforestry-Porang cultivation; b) increase knowledge and skills of farmers in harvesting and managing post-harvest of Porang; c) increase farmers' income from Porang; d) improve the HKm Farmer Group institution.

\section{LITERATURE OR CONCEPTUAL REVIEW}

\subsection{Porang (Amorphophallus onchophillus)}

Porang is a bulbous plant that can grow in shaded trees at intensity between $40-75 \%$ (Aprilia \& Harmayani, 2012; Aryani \& Budiadi, 2014). Introduction of Porang under forest stands began in the 1980s in Klangon, RPH Saradan, Madiun Regency and spread 
in East Java. Porang produces mannan flour or Konnyaku flour which in Japan is processed into various functional food ingredients (Konnyaku, 2015) for the prevention or treatment of diabetes and is good for digestion (Figure 1). Porang habitat in Malang, for instance, is located in the shade of surrounding vegetation. Many wild-growing Porang is found under bamboo stands, while Porang that is cultivated is widely grown under Teak stands (Alifianto et al., 2013).

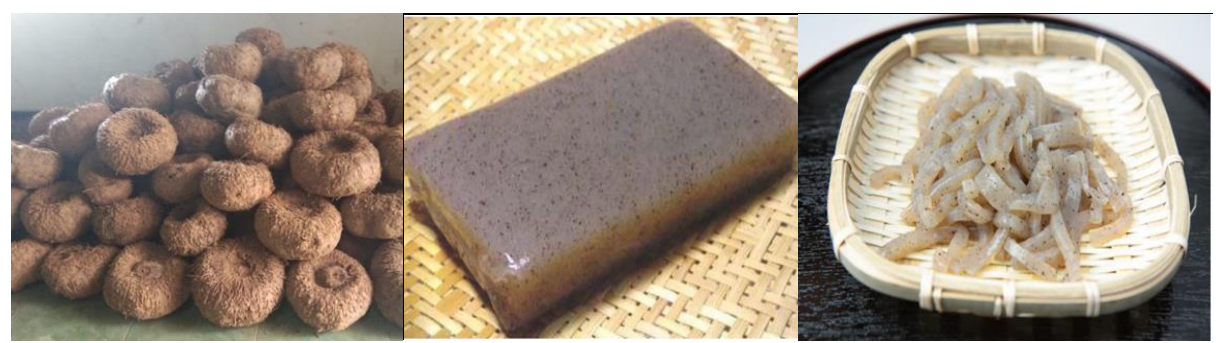

Source: ITPC Osaka (2014)

Figure 1. Porang tubers (left) and its derivative products (center and right) in the form of ready-to-eat food in Japan. (Source

Nowadays, Japan is a major producer of Konnyaku flour from the Amorpophallus konjac species (ITPC Osaka, 2014; Konnyaku, 2015). This type is actually cultivated without needing shade (Figure 2). In the case of KPH Saradan, Porang is able to grow well in various types of shading (Aryani \& Budiadi, 2014). According to Japanese Ministry of Finance's statistic (Figure 3), production of Porang tubers in the past five years always above 60,000 tons per year, except for 2013 due to climate change factors, and despite a fluctuating trend there was more than 70,000 tons in 2015 (Aprilia \& Harmayani, 2012; Aryani \& Budiadi, 2014). Japan also imports Konyaku flour from various countries in Southeast Asia, such as Myanmar, Laos, Thailand, and Indonesia (ITPC Osaka, 2014; Konnyaku, 2015). There is a tendency for Konnyaku flour imports from Indonesia to increase in the past seven years and even in 2014 defeated Myanmar, Laos, nd China (Figure 4). This is an opportunity for 
Indonesian government to increase exporting of Konnyaku flour by expanding adoption and diffusion of Porang tubers under forest stands (Kurniati et al., 2015).

(a)

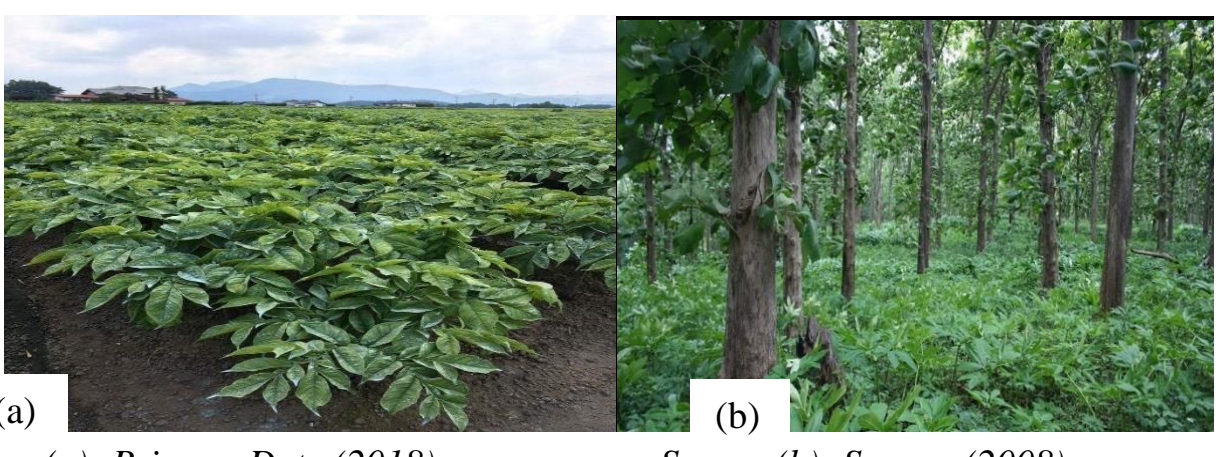

Source (a): Primary Data (2018)
Source (b): Sugayo (2008)

Figure 2. Comparison of locations where Amorphophallus konjac (a) grows in Japan and Amorphophallus oncophyllus (b) in Indonesia.

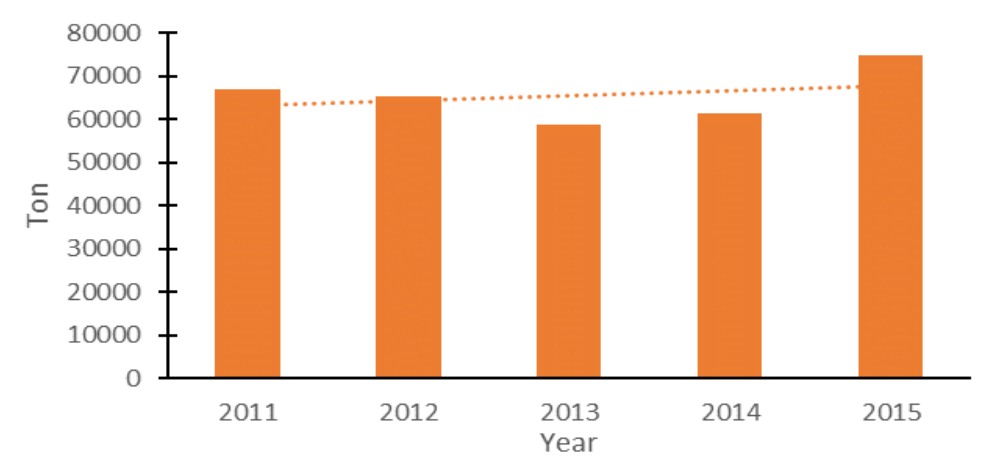

Source: Foreign Trade Statistics, Japanese Ministry of Finance (2015)

Figure 3. Development of Porang production in Japan in the past 5 years

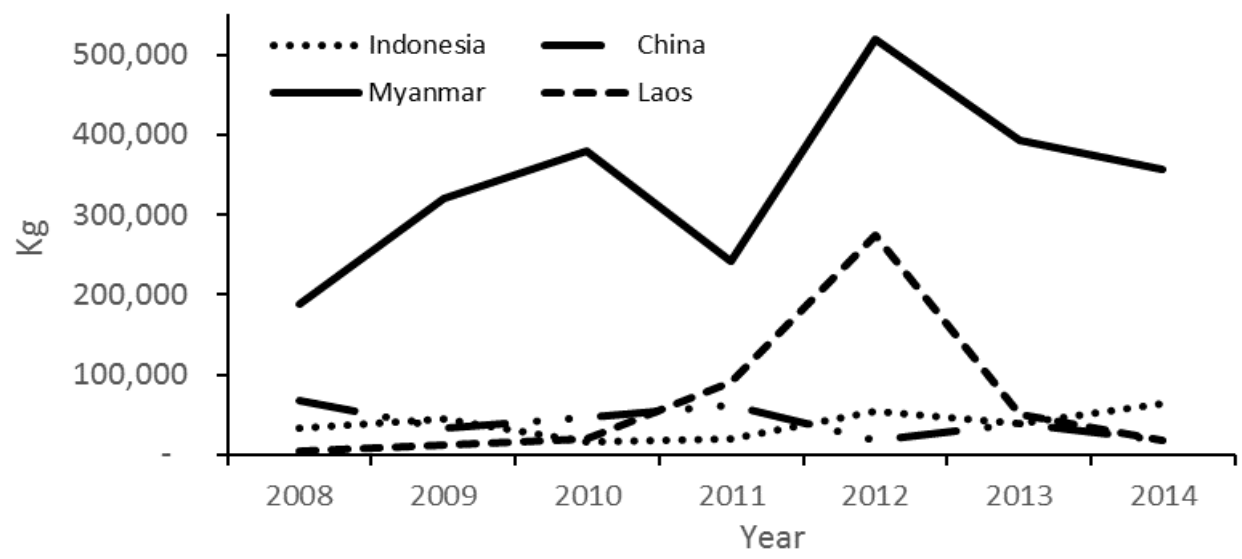

Source: Foreign Trade Statistics, Ministry of Finance of Japan (2015)

Figure 4. Development of Japanese Konnyaku (Porang) flour imports from countries in Southeast Asia over the past 7 years 
Several studies have shown contribution of Porang tubers increasing income of forest farming families (Puspitorini et al., 2018; Rofiqoh, 2018; Wahyono et al., 2017). Currently, price of Porang tubers is around Rp 4,500/kg of wet tubers or Rp 31,000/kg dried tubers. In one hectare, 5 - 6 tons of wet tubers may be obtained, so that the potential gross income from its tubers planted within one-hectare forest stands may reach $\mathrm{Rp} 25$ - 35 million/year. This amount is helpful to increase income of forest farmer families (Hufschimdt et al., 1987; Bull et al., 2005). This contribution should be doubled by improving intensive cultivation in terms of spacing and fertilization.

\subsection{Agroforestry}

Agroforestry is a system of land use (farming) that combines trees with agricultural crops to increase profits, both economically and environmentally. Its scheme is one of an effective methods of land management for equity and stages to overcome poverty in village forest community by contributing to household income 41.32 percent and employment of 2.39 people per ha (Mayrowani et al., 2016). Several benefits of applying its method, such as (1) increasing food production, farmer income, employment opportunities and increasing the quality of community nutrition so as to achieve farmers' welfare around forests; (2) increasing knowledge and skills of farmers to develop an agricultural intensification system in dry soils in the countryside which means increased productivity of dry agricultural land (moor), and (3) increasing public awareness of forest functions that are expected to reduce pressure against forest disturbances (Mayrowani et al., 2011). 


\subsection{Community Empowerment in Community Forestry (HKm)}

Community empowerment is an effort to empower people through a series of activities to strengthen weak groups in society, including individuals who experience poverty problems. Community empowerment in forest development is said to be successful if the community is able to: (1) analyze and develop the potential of the community independently, (2) eliminate dependency, (3) build and develop economic, political and cultural institutions in the community, (4) gender equality in forestry development, (5) developing democracy in the broadest sense, (6) daring to express aspirations and thoughts critically, (7) recognition of forest natural resources owned by communities, and (8) equality in program planning, implementation, monitoring and evaluation / forestry project. According to information from the Ministry of Environment and Forestry, up to 2010 there were more than 48 million people living around forest areas and their lives depended on products and services produced from forest resources.

Community Forestry $(\mathrm{HKm})$ as stated in Minister of Forestry Regulation No. P.37 / Menhut-II / 2007 are state forests whose utilization is primarily intended to empower communities in and around forest areas. Community empowerment is seen as an effort to improve the capacity and independence of the community so that they can obtain the benefits of forest resources optimally and fairly through developing capacity and providing access in the context of community welfare. An institutional institution is needed in community empowerment. Institutions are interpreted as a collection of values, norms, rules in a group of people, which are used to achieve certain goals. Each institution will have an institutional system that is tailored to the characteristics of its activities. Forest management is a forestry activity related to community development, 
community economic development, by maintaining and guaranteeing the preservation of natural resources.

\section{METHOD}

\subsection{Program}

Community services in Banyusoco Village are strongly supported by the Village Head and existing forest community groups. Its activity also a synergy with village program in improving community economy by developing potential of existing natural resources, where in future plans, Porang cultivation could also be used as an educational tourism destination in this village.

The approach that we used in the community service program is an articulate approach that combines findings of science and technology in the agroforestry-Porang model with bottom-up planning following aspirations of targeted group's needs at implementation level. Involvement of targeted group also considers gender aspects, namely balanced participation of women and men is calculated equally. Its involvement of women is focused on increasing contribution of women in income of forest farmer families, both in planning and post-harvest stages to become high-nutritious alternative food products. We planed three years program on this community services (Figure 5). 
Source: Primary Data (2018)

Figure 5. Roadmap for community services in 2018 - 2020.

We detailed our methods and mechanisms into three phases outlined in the three-year period:

Year I: Introduction of agroforestry-Porang models.

a. Workshop aims to introducing Porang cultivation, selecting land for demonstration plots, and organizing demonstration plot activities.

b. Cultivation Porang training.

c. Development of demonstration plots in the field included nursery preparation, land preparation, planting and maintenance on community forestry $(\mathrm{HKm})$.

d. Focus group discussion on HKm Farmer Group institution to arrange group rules related to Porang cultivation (site selection, workload distribution rules and distribution of benefits within farmer groups)

Year II: Harvesting and utilization of appropriate technology for processing Porang tubers.

a. Workshop includes technical harvesting, processing Porang tubers into chips and utilizing appropriate technology for processing products.

b. Industrial visit of processing Porang tuber into Konnyaku flour. 
c. Sales of tubers and chips to Konnyaku flour processing industries.

Year III: Extensification of village level agroforestry-Porang models

a. Workshop on development of village level agroforestry models.

b. Expansion of planting areas in community and state forests involving Banyusoco BUMDES (Village-owned business entity).

c. Improved network on marketing.

\subsection{Outcome}

Our community services could be categorized as successful if there is a change in better condition of community. Our expected outcome of the implementation of the agroforestry-Porang model on community land is being able to increase contribution of forest land to increasing income of farmer families:

a. The Banyusoco Village community is able to intensify the land under forest stands with an agroforestry-Porang model proven by percentage of successful planting of Porang.

b. Banyusoco Village community is able to monitor and evaluate agroforestry-Porang models to improve management of Porang planting.

c. The Banyusoco Village community have good institutions through community empowerment.

\section{RESULTS AND DISCUSSION}

\subsection{Socialization and Focus Group Discussion (FGD)}

Our initial outreach and coordination of community service program plan has been carried out since April 2018. First coordination meeting with village community was 
held on 06 May 2018 attended by the HKm chairperson, administrators and members of HKm ‘Sedyo Rukun’ and village head.

During socialization and FGD, various information was obtained. First, the management and members of $\mathrm{HKm}$ and village officials were welcome and agreed to our program. Water needs in Banyusoco Village are very important things to fulfill because besides being needed for daily needs, water is also necessary for the success of agroforestry-Porang cultivation. Second, community input is still around water needs that need to be met so that the program runs well. Information on water sources has also been obtained, the distance of water sources is relatively not far away (app. $2 \mathrm{~km}$ ) but access is difficult because of steep topography. Third, the community has explained history of planting other crops such as Kara Beguk (Mucuna pruriens) and ginger that have been carried out even though they were not successful due to lack of water and late planting time (end of rainy season). This can be a lesson for this service program later. Fourth, the community is quite skilled in working on the land. They have participated in several trainings and assistance from the JAVLEC, Forestry and Plantation Service and Non-Governmental Organizations. Looking at the background of their skills and enthusiasm of community, this program is ready to be implemented. Fifth, the coordination among members to determine work tasks, land to be cultivated, and technical training on the cultivation of Porang at the next meeting. Its FGD resulted execution of division of work assignments, land to be cultivated, as well as technical training on Porang cultivation. 


\subsection{Workshop}

Field workshops prepared rules about contribution of UGM and community in preparation of Porang cultivation activities were carried out on 31 July 2018 (Figure 6). This workshop was held to prepare where demonstration plots would be developed, how to prepare the community for what to accept and what to sacrifice in the construction of Porang demonstration plot. Based on this workshop, it was agreed that a good location for planting Porang was in Plot 95 Block 2 with a planned spacing of 1x0.5 m. In Block 2, teak plants are planted with $4 \times 2 \mathrm{~m}$ spacing of 3 ha. However, for the size of demonstration plot was agreed that an area of 0.5 ha with a size of $50 \times 100 \mathrm{~m}$. The reason of 0.5 ha is due to first trial of Porang tuber cultivation and also limited budget of community service program to supply seeds, fertilizers, focus group discussion, and other supported program for community.

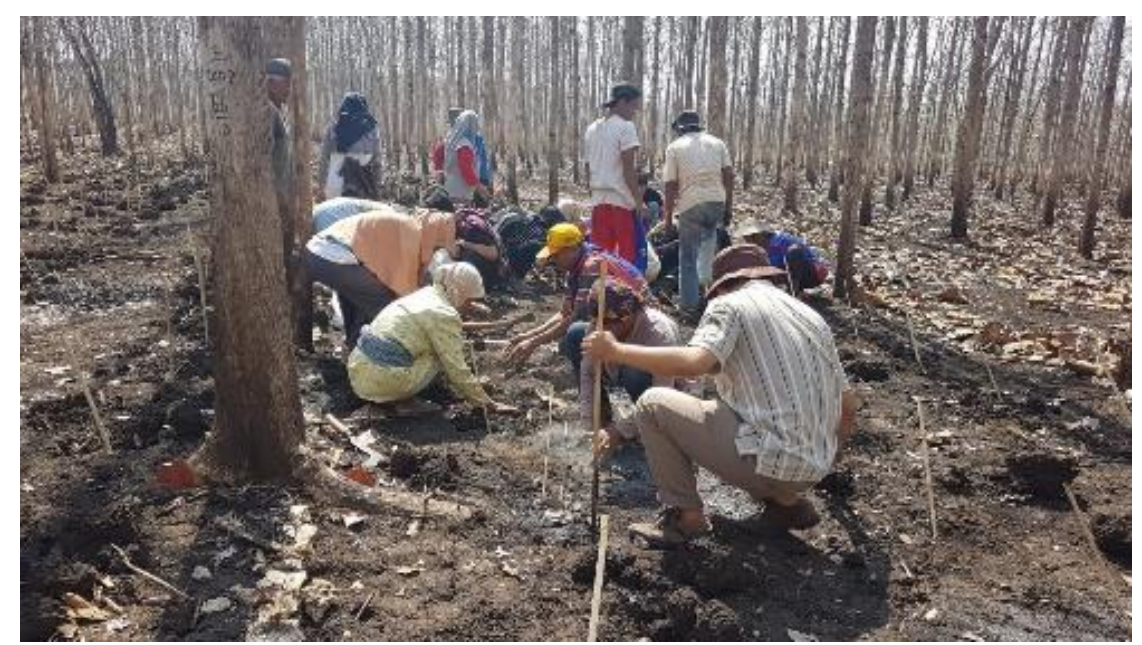

Source: Primary Data (2019)

Figure 6. Direct workshop on cultivating Porang under Teak stands with community forestry group HKm "Sedyo Rukun".

The people that will be cultivated come from large bulbs and frogs with an estimated harvest in the next year. Porang cultivation activities will be coordinated by HKm chairperson herself. For the plan to share results, agreed percentage of results 
were discussed together with all group members and each of them will get a fair share. Activities are expected to be sustainable with assistance by UGM so that later the community can independently cultivate themselves. Our next plan for developing Porang will be adjusted to planned teak felling block. Our comparative study to other sites were planned to Porang cultivation centers, such as in Saradan, Madiun, and Nganjuk to get a network of cooperation and markets including get better knowledge in Porang cultivation. For the plan to share the results, the agreed percentage of results will be discussed together with all group members and each will get a fair share. Later, people will also be cultivated further on privately owned land (land with an area of 0.5 hectares).

\subsection{Demonstration Plot}

Development of demonstration plot began on August 2018 (Figure 7). Preparation of Porang cultivation land was carried out based on the results obtained during the Porang cultivation preparation workshop. Land preparation includes land clearing, manufacture of pickles (acir) and installation in on August 1-3, 2018. Acir with a height of 0.5 meters was prepared for 2000 pickles installed on 04 August 2018. Time for making holes which was continued with provision of manure agreed by members themselves, after the Indonesian independence and Eid al-Adha events follow the availability of time by the group. This land preparation activity was carried out jointly by all members voluntarily. 


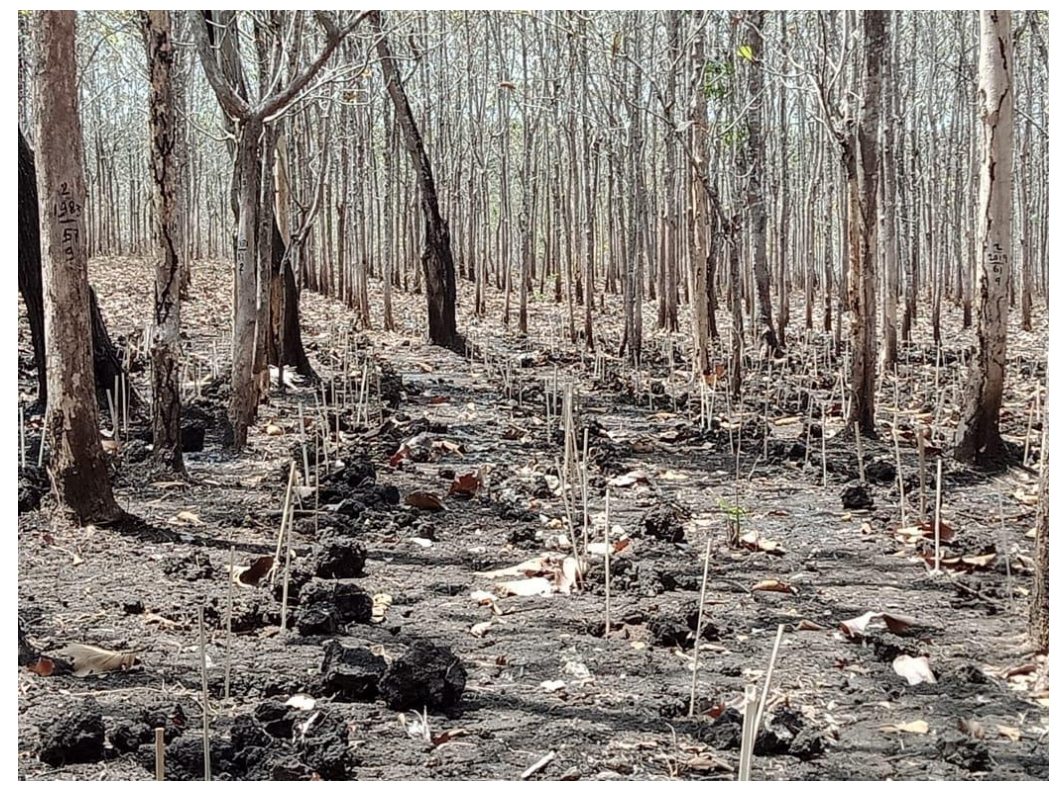

Source: Primary Data (2019)

Figure 7. Development of a 0.5 ha-demonstration plot with 4,000 seeds in Banyusoco village.

Land preparation activity was coordinated by chairman and his representative. Before Porang was planted, it has been prepared in the yard and under Teak stands stand for approximately one week. This land preparation work was carried out in mutual cooperation once a week every Thursday or according to agreement without any incentives from the program. After land preparation for Porang cultivation, initial planting was carried out starting 22 September 2018 jointly with UGM team.

\subsection{Evaluation of Community Empowerment Programs}

Our first one-year program of community empowerment has been done. It was not a perfect activity, therefore we evaluated our program through indicator target achievement (Table 1). 


\section{Table 1. Evaluation of community empowerment program through indicator} achievement.

\begin{tabular}{|c|c|c|c|}
\hline No & Target & Indicator & Achievements of Program \\
\hline a. & $\begin{array}{l}\text { Intensify the land under } \\
\text { forest stands with an } \\
\text { agroforestry-Porang } \\
\text { model }\end{array}$ & $\begin{array}{l}\text { Land planted with } \\
\text { Porang cultivation }\end{array}$ & $\begin{array}{l}\text { Development of a } 0.5 \text { ha- } \\
\text { demonstration plot with } \\
4,000 \text { seeds }\end{array}$ \\
\hline b. & $\begin{array}{l}\text { Monitor and evaluate } \\
\text { agroforestry-Porang } \\
\text { models }\end{array}$ & $\begin{array}{l}\text { Percentage of } \\
\text { successful planting } \\
\text { of Porang }\end{array}$ & $\begin{array}{l}\text { Monitoring visually has been } \\
\text { done, but it was not } \\
\text { percentaged }\end{array}$ \\
\hline \multirow[t]{3}{*}{ c. } & $\begin{array}{l}\text { A good institution is } \\
\text { formed }\end{array}$ & $\begin{array}{l}\text { Establishment of } \\
\text { policies, clear } \\
\text { strategies }\end{array}$ & $\begin{array}{l}\text { A plan and procedure for } \\
\text { cultivating Porang has been } \\
\text { formed and agreed and } \\
\text { understood by members of } \\
\text { the institution }\end{array}$ \\
\hline & & $\begin{array}{l}\text { Structure and } \\
\text { process in } \\
\text { institutions are } \\
\text { formed }\end{array}$ & $\begin{array}{l}\text { The person in charge of each } \\
\text { activity from Porang } \\
\text { cultivation has been formed. } \\
\text { Several processes have also } \\
\text { been carried out }\end{array}$ \\
\hline & & $\begin{array}{l}\text { Clear financial } \\
\text { system }\end{array}$ & $\begin{array}{l}\text { The profit sharing and } \\
\text { financial plan has been } \\
\text { agreed on how it will be } \\
\text { carried out. But it has not yet } \\
\text { been formed because funds } \\
\text { from harvesting activities } \\
\text { have not been implemented }\end{array}$ \\
\hline \multirow[t]{3}{*}{ d. } & $\begin{array}{l}\text { Increased motivation of } \\
\text { each individual in the } \\
\text { activity }\end{array}$ & $\begin{array}{l}\text { Increased } \\
\text { community } \\
\text { participation }\end{array}$ & $\begin{array}{l}\text { The community actively } \\
\text { participates in every Porang } \\
\text { cultivation activity }\end{array}$ \\
\hline & & $\begin{array}{l}\text { Increased } \\
\text { percentage of land } \\
\text { use }\end{array}$ & $\begin{array}{l}\text { The land used temporarily is } \\
\text { the state forest area. The next } \\
\text { plan will be cultivated on } \\
\text { own land }\end{array}$ \\
\hline & & $\begin{array}{l}\text { The increasing } \\
\text { percentage of } \\
\text { successful Porang } \\
\text { cultivation }\end{array}$ & $\begin{array}{l}\text { Not yet seen because the } \\
\text { activity has not been } \\
\text { completed }\end{array}$ \\
\hline
\end{tabular}

Source: Primary Data (2019) 


\subsection{Challenges and solutions}

We need to adjust minor program after experienced several challenges in Porang cultivation. The following are challenges and methods of anticipation faced by the team during implementing our program. Existence of service activities which coincided with fasting period and long-Eid holiday made several planned visits to the field postponed after Eid holidays. However, internal discussion of UGM team to discuss next plan and communication with Banyusoco Village representatives continued throughout period via Whatsapp with HKm chairperson and Village Head. Secondly, other potential technical obstacles were limited water on community lands which may potentially inhibit the growth of Porang plants. Experience of Watershed Management Center (BPDAS) that planted ginger (Zingiber officinale) under teak stands also did not grow well.

Additionally, Garut (Maranta arundinacea) planting by the Agriculture Service has also not been harvesting since 2015, and also planting Kara Benguk (Mucuna pruriens) in the same year has also not produced fruits. With proper land preparation and timing (land preparation at the end of the dry season and planting before the rainy season), it was expected the tubers may cope to grow optimally during rainy season. Research also shows the importance of climate variables (temperature and rainfall) that have a positive correlation with the oxalate content of Porang tubers (Indriyani, 2010). Third, in the procurement of Porang seeds, our team faced the problem of increasing price of Porang seeds from previous year. This made our target area for Porang planting likely to be adjusted and type of seedlings used more bulbils than tubers, therefore harvest period was also expected to retreat. The increase in tuber prices also brings hope that selling prices of bulbs and bulbs from these trials will be higher in the future. 
Program Reflection Firstly, Banyusoco Village's community who are members of HKm 'Sedya Rukun' are able to organize themselves in accepting outside intervention, for instance from UGM. This could be seen from their response of administrators and community members who enthusiastically welcomed the land intensification program under forest stands with the agroforestry-Porang model. This form of self-organization was seen from the presence in routine meetings and presence of mutual cooperation in creation of demonstration plots in the field. Its group organizing pattern follows "sripah management".

In sripah management, each person or group should do specific tasks when there was death among members of community, likewise, in construction of demonstration plot. In its implementation, women's groups were tasked with clearing land, starting from collecting litter and burning it in a controlled manner. In addition, they also prepared to consume potluck snacks and breakfast or BYWO (bring your own plate). While the male group was looking for bamboo trees, cutting into a certain size. They also made planting holes, and collect fertilizer, while planting work was done by both male and female groups.

Secondly, the community learned from land intensification program under previously failed stands. According to them, a number of failed programs were caused by inaccurate planting times where its program was carried out in a top down and very late in providing seed assistance. The timing of planting at the end of rainy season causes growth of tubers not to develop when facing dry season. In addition, absence of technical assistance in land preparation and planting led to failure of previous PLDT program. 


\section{CONCLUSIONS AND SUGGESTIONS}

Our first of three year activities program included institutional workshops and introduction of Porang cultivation, procurement of Porang seeds, development of demonstration plot, and facilitation on planting Porang under stands have been done. These activities increase environmental knowledge and skills of farmers in agroforestryPorang cultivation in Banyusoco village as well as improving HKm Sedyo Rukun as farmer group institution. We are continuing our next two year-program of agroforestry Porang in managing post-harvest to increase farmers' income from Porang production.

Based on our experience in community service program in Banyusoco village, Gunung Kidul, we suggest to be considered in developing PLDT are as follows. First, the need for socialization and discussion that provides an overview of where program will be directed. Visualization of final goal of program may use documentary films or images of actual conditions desired in the future or empirically practiced. Second, need to strengthen institutions by making clear rules of the game about what to do, who will do what, who will give what and what to get. Third, the need for assistance in every activity in the field so that there is appropriate technology transfer and communication between members and administrators. Explanation and giving direct examples in the field of the cultivation techniques carried out may increase their confidence in what they are doing.

\section{ACKNOWLEDGMENTS}

This research was supported and funded by Faculty of Forestry Universitas Gadjah Mada. The authors would like to thank community forestry group HKm "Sedyo Rukun" and Banyusoco village for great collaboration on our community services program. 


\section{REFERENCES}

Alifianto, F., Azrianingsih, R., \& Rahardi, B. (2013). Peta persebaran porang (Amorphophallus muelleri Blume) berdasarkan topografi wilayah di Malang Raya. Biotropika: Journal of Tropical Biology, 1(2), 75-79. https://biotropika.ub.ac.id/index.php/biotropika/article/view/136/118.

Aprilia, V., Harmayani, E. (2012). Karakterisasi dan potensi prebiotik glukomanan dari umbi porang (Amorphophallus oncophyllus Prain). Master Thesis, Faculty of Agricultural Technology, Universitas Gadjah Mada, Indonesia. Not published.

Aryani, D.P. \& Budiadi. (2014). Produktifitas umbi porang di bawah tegakan jati dan sonokeling di KPH Saradan. Undergraduate Thesis, Faculty of Forestry, Universitas Gadjah Mada, Indonesia. Not published.

Bull, G., Jayasinge, P., \& Schwab, O. (2005). Economic indicators and their use in Sustainable forest management. BC Journal of Ecosystems and Management, 8(2), 37-45. http://www.forrex.org/publications/jem/ISS41/vol8_no2_art3.pdf.

Buongiorno, J. \& Gilles, K. (2003). Decision methods for forest resources management. San Diego, California: Kluwer Academic Publishers.

Desa Banyusoco. (2014). Desa Banyusoco, Kecamatan Playen, Kabupaten Gunungkidul. Retrieved February 26, 2018, from https://banyusocoplayen.desa.id/index.php/first.

Hufschimdt, M.M., James, D.E., Meister, A.D., Bower, B.T., \& Dixon, J.A. (1987). Environmental Natural System and Development an Economic Valuation Guide. (Indonesian Edition: Lingkungan Sistem Alami dan Pembangunan, Petunjuk Penilaian Ekonomis). Gadjah Mada University Press. Yogyakarta. 
Indriyani, S., Arisoesilaningsih, E., Wardiyati, T. \& Purnobasuki, H. (2010). Hubungan faktor lingkungan habitat porang (Amorphophallus muelleri Blume) pada lima agroforestri di Jawa Timur dengan kandungan oksalat umbi. $7^{\text {th }}$ Basic Science National Seminar Proceeding at Universitas Brawijaya, Malang (Vol. 20).

ITPC Osaka. (2014). Market Brief: Konnyaku. http://itpc.or.jp/wpcontent/uploads/2014/08/MB-Oktober-2014-Konnyaku.pdf.

Kurniati, H., Rahayoe, S., \& Harmayani, E. (2015) Karakteristik pengeringan chips porang menggunakan cabinet dryer dengan variasi suhu dan ketebalan irisan. Undergraduate Thesis, Faculty of Agricultural Technology, Universitas Gadjah Mada, Indonesia. Not published.

Konnyaku. (2015). Welcome to "Konjac World". Retrieved January 12, 2018, from http://www.konnyaku.or.jp/En/index.html.

Mayrowani, H. (2016). Pengembangan agroforestry untuk mendukung ketahanan pangan dan pemberdayaan petani sekitar hutan. Forum Penelitian Agro Ekonomi, 29(2), 83-98.

\section{http://ejurnal.litbang.pertanian.go.id/index.php/fae/article/view/3893/3235.}

Puspitorini, P. S., Putra, A. C., \& Ernes, A. (2018). Pemberdayaan Petani Porang Dengan Konsep Terintegrasi Melalui Kuliah Kerja Nyata Program Pembelajaran Masyarakat. Prosiding PKM-CSR, 1, 1671-1678.

Rofiqoh, R. (2018). Perubahan Kondisi Sosial Ekonomi Masyarakat Desa Sekitar Hutan Dalam Usahatani Porang (Amorphophallus Muelleri B.) Di Desa Bendoasri, Kabupaten Nganjuk (Doctoral dissertation, Universitas Brawijaya).

Wahyono, A., Arifianto, A. S., Wahyono, N. D., \& Riskiawan, H. Y. (2017). Prospek ekonomi kebijakan pemanfaatan produktivitas lahan tidur untuk pengembangan 
porang dan jamur tiram di jawa timur. Cakrawala. Jurnal Litbang Kebijakan, 11(2), 171-180. https://doi.org/10.32781/cakrawala.v11i2.17.g17. 